\title{
Application of handheld XRF spectrometers for estimation of Rare Earth Elements content in alkaline intrusions from the East European Craton (NE Poland) - preliminary results
}

\author{
Magdalena Pańczyk, Jakub Bazarnik, Jerzy Nawrocki, \\ Leszek Giro, Ewa Krzemińska \\ Polish Geological Institute - Polish Research Institute, Micro-area Analysis Laboratory; ul. Rakowiecka 4, 00-975 Warsaw, \\ Poland; e-mail: Magdalena.Panczyk@pgi.gov.pl,Jakub.Bazarnik@pgi.gov.pl
}

(C) 2015 Authors. This is an open access publication, which can be used, distributed and reproduced in any medium according to the Creative Commons CC-BY 4.0 License requiring that the original work has been properly cited.

The Carboniferous alkaline intrusions, which cut the Precambrian basement of East European Platform are known only from drillings. The massifs are covered by Mesozoic and Cenozoic sediments $(600-800 \mathrm{~m})$ and their borders were defined by extensive geophysical investigations.

The Tajno alkaline-carbonatite complex, the Ełk syenite massif, the Pisz gabbro-syenite complex as well as alkaline rocks recognized as Mława or Olsztynek anomaly are the subject of systematic and complex analyses. All of them could be the potential sources for rare earth elements. The massifs were explore by several boreholes (about 12,000 m of drill core material; e.g. Ełk IG 1-4, Tajno IG 1-12, Prostki 1-2, Klusy-1, Grajewo IG-1). Thus, the main aim of our study is to precisely identify the perspective drill-core intervals within the Ełk IG4 borehole materials for better defining of locations for detailed sampling and further laboratory analysis. For this purpose we had applied handheld XRF DELTA 50 Premium spectrometers equipped with a $4 \mathrm{~W}$ Ta anode X-ray tube $(50 \mathrm{kV})$. The parameters of spectrometers (higher voltage and multi-beam system) are optimized for rare earth elements (REEs) such as Y, $\mathrm{La}, \mathrm{Ce}$, Pr, Nd. Handheld XRF non-destructive analyses allowed the identification of mineralized trends and anomalies within the drill-core material at the ppm level. The previous testing analyses enabled to optimize times of acquisition for each beam and provide fast field analyses (about 100 per day).

The contents of La and Ce were chosen as indicators of the REE-bearing minerals occurrence in analyzed rocks. The XRF analyses were performed for each meter of drill core. The graph of these elements content vs. depth of the samples from Ełk IG4 borehole exhibited high differentiation. The highest and lowest content of La was $17 \mathrm{ppm}$ and $3241 \mathrm{ppm}$, respectively (average $167 \mathrm{ppm}$ for 1185 samples, without 78 below the level of detection) and $\mathrm{Ce}-24 \mathrm{ppm}$ and $4313 \mathrm{ppm}$ (average $294 \mathrm{ppm}$ for 1214 samples, without 49 below the level of detection). The higher content of REE elements seems to be related to concentration of minerals such as pyroxene, mica, titanite, monazite, zircon, fluoro-carbonate as well as the presence of secondary veins in smaller amounts.

This research is supported by the Ministry of the Environment of Poland from the sources of the $\mathrm{Na}$ tional Fund for Environmental Protection and Water Management. 